\section{THE FIRST LOGISTIC PRACTICUM}

On 11 May 2015 the Faculty of Transport and Traffic Sciences, University of Zagreb and the Students Association Trans of the Faculty of Transport and Traffic Sciences organized the First Logistic Practicum. The Practicum was held at the Faculty premises, at the University Campus Borongaj, and it was attended by forty students from the Faculty of Transport and Traffic Sciences and the Faculty of Economics, University of Zagreb.

The Logistic Practicum is an innovative project aimed at improving the knowledge and business competences of students through physical simulation of real business processes. Through various simulations the students had the opportunity to show how skilful they are in practical implementation of the acquired knowledge in the field of logistics and management.

Within classical education the students have no opportunity to acquire competences of teamwork and coping with contingencies. By participating in this project the students developed these skills, and the event encouraged a competitive spirit and teamwork.

The importance of the project is reflected in coordinated cooperation and joint performance of the scientific institutions, economic entities and student associations. The entrepreneurs, to whom logistic processes are part of everyday business, participated in the project as simulation creators and as assessors of the winning team, and gave at the end of simulation their review of the course and results of simulation

This year, as part of the Logistic Practicum three simulations were realized. The first one under the title Management Game sponsored by the Kuehne + Nagel Hrvatska Ltd. Company, under the control and a commentary given by Mr. Aleš Sklepić, Head of the Maritime Department. The second simulation dealt with inventory management, sponsored by the Kraš d.d. company, under the surveillance and commentary by Ms. Branka Tokić, the planning project manager. The third simulation entitled Lean Management helped the students in solving logistical processes in the production, and the sponsor was Voćarski centar Ivković.

As part of the Logistic Practicum a Round table was held entitled "Impact of Simulations on Business Competences". The moderator was Assistant Professor Nikolina Brnjac, Ph.D. from the Faculty of Transport and Traffic Sciences, and the round table participants were Mr. Sklepić, Head of the Maritime department of Kuehne + Nagel Hrvatska Ltd., Mr. Pavić, Assistant

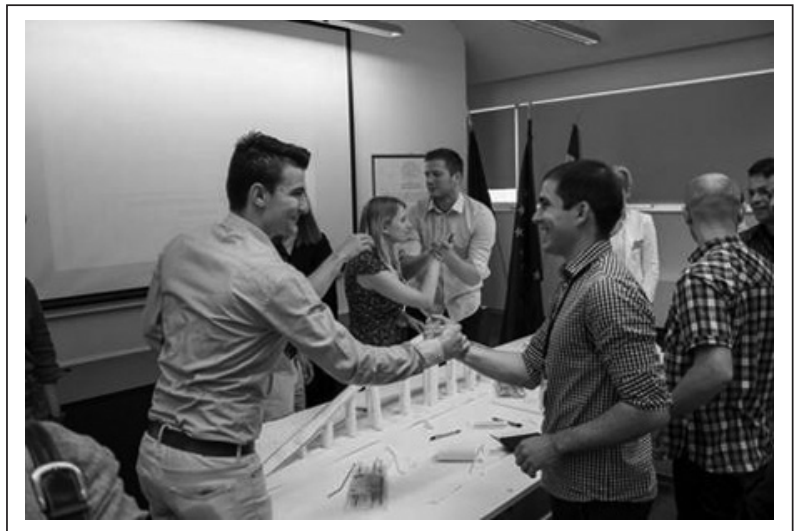

Celebrating the completion of building a bridge in a simulation entitled Management Game

Director of PTP Sector for Planning, Mr. Hirtz, owner and director of the Integralog Ltd. Company, Mr. Zrilić, Board member and consultant of the Logiko, Ltd. Company, and Prof. Rogić, Ph.D., Head of the Department for Transport Logistics of the Faculty of Transport and Traffic Sciences. It was concluded that the project realized all the set goals and the Logistic Practicum is expected to be held during the next years for the future generations of students.

The simulations that were carried out and monitored in phases showed that the students achieved from phase to phase always better results, i.e. realized bigger profit in the operation of simulated companies. The students developed over time more harmonious and organized relations in the team and took over specific functions and in this way set better organization of the processes, which ultimately gave a better result.

The discussion at the round table emphasised the importance of linking science, economy and students, and this is precisely what was achieved by the project. The future development of the project can go in the direction of realizing adequate training for the logistic industry workers, with the inclusion of businessmen in devising simulations in order to be able to make better assessment of the potentials of the logistic branch employees.

\footnotetext{
Assoc.Prof. Jasmina Pašagić Škrinjar, Ph.D. President of the Organizing Committee Department of Transport Logistics Faculty of Traffic and Transport Sciences University of Zagreb
} 